Foss. Rec., 24, 135-139, 2021

https://doi.org/10.5194/fr-24-135-2021

(C) Author(s) 2021. This work is distributed under

the Creative Commons Attribution 4.0 License.

\title{
First record of the subfamily Sagrinae (Coleoptera: Chrysomelidae) from the Eocene of North America
}

\author{
Andrei A. Legalov ${ }^{1,2,3}$ \\ ${ }^{1}$ Institute of Systematics and Ecology of Animals, Siberian Branch, Russian Academy of Sciences, Frunze Street 11, \\ Novosibirsk 630091, Russia \\ ${ }^{2}$ Department of Ecology, Biochemistry and Biotechnology, Altai State University, Lenina 61, Barnaul 656049, Russia \\ ${ }^{3}$ Department of Forestry and Landscape Construction, Tomsk State University, Lenin Ave 36, Tomsk 634050, Russia
}

Correspondence: Andrei A. Legalov (fossilweevils@gmail.com)

Received: 10 March 2021 - Revised: 15 April 2021 - Accepted: 15 April 2021 - Published: 12 May 2021

\begin{abstract}
A new genus, Palaeatalasis gen. nov. (type species P. monrosi sp. nov.), from the tribe Megamerini (Chrysomelidae: Sagrinae) from the early-middle Eocene Green River Formation is described and illustrated. The new genus is similar to the Recent Atalasis Lacordaire, 1845 but differs from it in the subparallel sides of the pronotum, metafemora without teeth, and non-emarginate eyes. It differs from the Eocene Eosagra Haupt, 1950 in the large, convex, non-emarginate eyes, wide elytra, and transverse pronotum. The new genus is distinguished from the Paleocene Gallopsis Legalov, Kirejtshuk et Nel, 2019 in the wide forehead and convex eyes. It is the first record of the Sagrinae from North America and the fourth known species of the family Chrysomelidae from the Green River.
\end{abstract}

\section{Introduction}

Leaf beetles of the family Chrysomelidae, which are common inhabitants of Recent ecosystems, develop on leaves or in different plant organs. Twelve subfamilies, Sagrinae, Bruchinae, Donaciinae, Criocerinae, Cassidinae, Chrysomelinae, Galerucinae, Eumolpinae, Lamprosomatinae, Cryptocephalinae, Spilopyrinae, and Synetinae, can be distinguished within the family (Bouchard et al., 2011; Reid, 2014). The earliest record of the subfamily Chrysomelinae is in the Middle-Late Jurassic of Kazakhstan (Kirejtshuk et al., 2015), but these data require confirmation. The second fossil find of this subfamily was from the middle Eocene of Germany (Haupt, 1956). The first record of Bruchinae was from the mid-Cretaceous Burmese amber (Legalov et al., 2020), Galerucinae from the Santonian Taimyr amber (Nadein and Perkovsky, 2018), Donaciinae from the Danian of Russia (Bieńkowski, 2015) and the late Palaeocene of Canada (Askevold, 1990), Sagrinae and Cryptocephalinae from the middle Paleocene of France (Piton, 1940; Legalov et al., 2019), Eumolpinae from the early Eocene Oise amber (Moseyko et al., 2010), Cassidinae from the early-middle Eocene of the USA (Chaboo and Engel, 2009), and Criocerinae from the late Eocene Baltic amber (Bukejs and Schmitt, 2016). The Lamprosomatinae were described from Baltic amber (Bukejs and Nadein, 2015; Bukejs, 2019). The Spilopyrinae and Synetinae are absent from the fossil history. The fauna of Chrysomelidae from the Green River Formation (late-middle Eocene, USA) is poorly studied. Only three species, Eosacantha delocranioides Chaboo et Engel, 2009, Denaeaspis chelonopsis Chaboo et Engel, 2009 of the Cassidinae, and Cryptocephalus vetustus Scudder, 1878 of the Cryptocephalinae, were described. Lema pervetusta Cockerell, 1921, which was listed from the Green River deposits (Santiago-Blay, 1994), belongs to the family Cerambycidae (Bukejs and Schmitt, 2016). The species described in this study is the first find of the subfamily Sagrinae and the fourth species of the family Chrysomelidae from the Green River Formation.

\section{Material and methods}

The holotype is deposited in the Institute of Systematics and Ecology of Animals of the Siberian Branch of the Russian Academy of Science (Russia: Novosibirsk) - ISEA. 
Descriptions, photographs, and body measuring were performed using a Zeiss Stemi 2000-C dissecting stereomicroscope.

Terminology of body structures is based on Lawrence et al. (2010).

This article is registered in ZooBank (http: //www.zoobank.org, last access: 16 April 2021) under LSID LSIDurn:lsid:zoobank.org:pub:A2F174B6-F4C745E7-9CAD-EA6EF89051A6.

\section{Systematic paleontology}

Order Coleoptera Linnaeus, 1758

Suborder Polyphaga Emery, 1886

Superfamily Chrysomeloidea Latreille, 1802

Family Chrysomelidae Latreille, 1802

Subfamily Sagrinae Leach, 1815

Tribe Megamerini Chapuis, 1874

Genus Palaeatalasis gen. nov.

urn:lsid:zoobank.org:act:163BA475-CC4E-42DB-

A101-E5BF2FD11C3F

\section{Type species}

Palaeatalasis monrosi sp. nov., herein designated.

\section{Etymology}

The name is formed from the Greek "palaios" (ancient) and the generic name "Atalasis". Gender masculine.

\section{Diagnosis}

Large distinctly sclerotized beetle; head prognathous, without middle sulcus, not constricted behind eyes; mandibles large; maxillary palpi long; eyes suboval, convex, nonemarginate; forehead wider than width of rostrum base; temples long; antennae filiform, reaching anterior third of elytra; pronotum transverse; sides subparallel; elytra suboval, striate; sutural stria deep, deeper than other striae; profemora and mesofemora moderately thickened; metafemora not toothed, distinctly larger than other femora; abdominal ventrite 1 long, 2.5 times as long as ventrite 2 .

\section{Comparison}

The new fossil genus is similar to the Recent Atalasis Lacordaire, 1845 but differs from it in the subparallel sides of the pronotum, non-emarginate eyes, and metafemora lacking teeth, whereas Atalasis is characterized by the pronotal sides tapering from the apical part to the basal third, emarginate eyes, and metafemora with teeth. It differs from the Eocene Eosagra Haupt, 1950 in the large, convex, non-emarginate eyes, wide elytra, and transverse pronotum. The new genus is distinguished from the Paleocene Gallopsis Legalov, Kirejtshuk et Nel, 2019 by the wide forehead and convex eyes.

\section{Remarks}

The head not narrowed basally, without rostrum, filiform antenna, and striate elytra suggest placement of Palaeatalasis gen. nov. in the family Chrysomelidae. The new genus belongs to the family Sagrinae based on the deep sutural stria, deeper than other striae, the metafemora distinctly larger than other femora, and the prognathous head without a median sulcus. The convex and non-emarginate eyes suggest placement in the tribe Megamerini.

Palaeatalasis monrosi sp. nov. urn:Isid:zoobank.org:act:EFC39195-89EF-4C8EB735-EE9777BF6A34

Figs. 1-2

\section{Etymology}

Patronymic. This new species is named in memory of Francisco Monrós, who studied Chrysomelidae.

\section{Type material}

Holotype. Holotype, ISEA, no. GR2020/2, counterpart of beetle.

\section{Type stratum}

Early-middle Eocene, Bridgerian, 53.5-48.5 Ma.

\section{Type locality}

United States: Utah, Uintah County, 3-4 km west of the railway crossing of the Green River, Green River Formation.

\section{Description}

Measurements. Body length (without rostrum) $17.7 \mathrm{~mm}$, body maximum width $7.8 \mathrm{~mm}$; pronotum length $3.5 \mathrm{~mm}$, pronotum maximum width $3.6 \mathrm{~mm}$; length of antenna $9.2 \mathrm{~mm}$

Body. Brown, distinctly sclerotized.

Head. Prognathous, without middle sulcus and without rostrum. Head capsule not constricted behind eyes. Labrum free. Mandibles large, curved. Maxillary palpi long. Eyes large, suboval, strongly convex, non-emarginate. Forehead wide, distinctly wider than width of rostrum base. Temples long, 0.6 times as long as eye length.

Antennae. Antennae inserted before eyes, filiform, long, reaching anterior third of elytra. Antennomere 1 oval, 


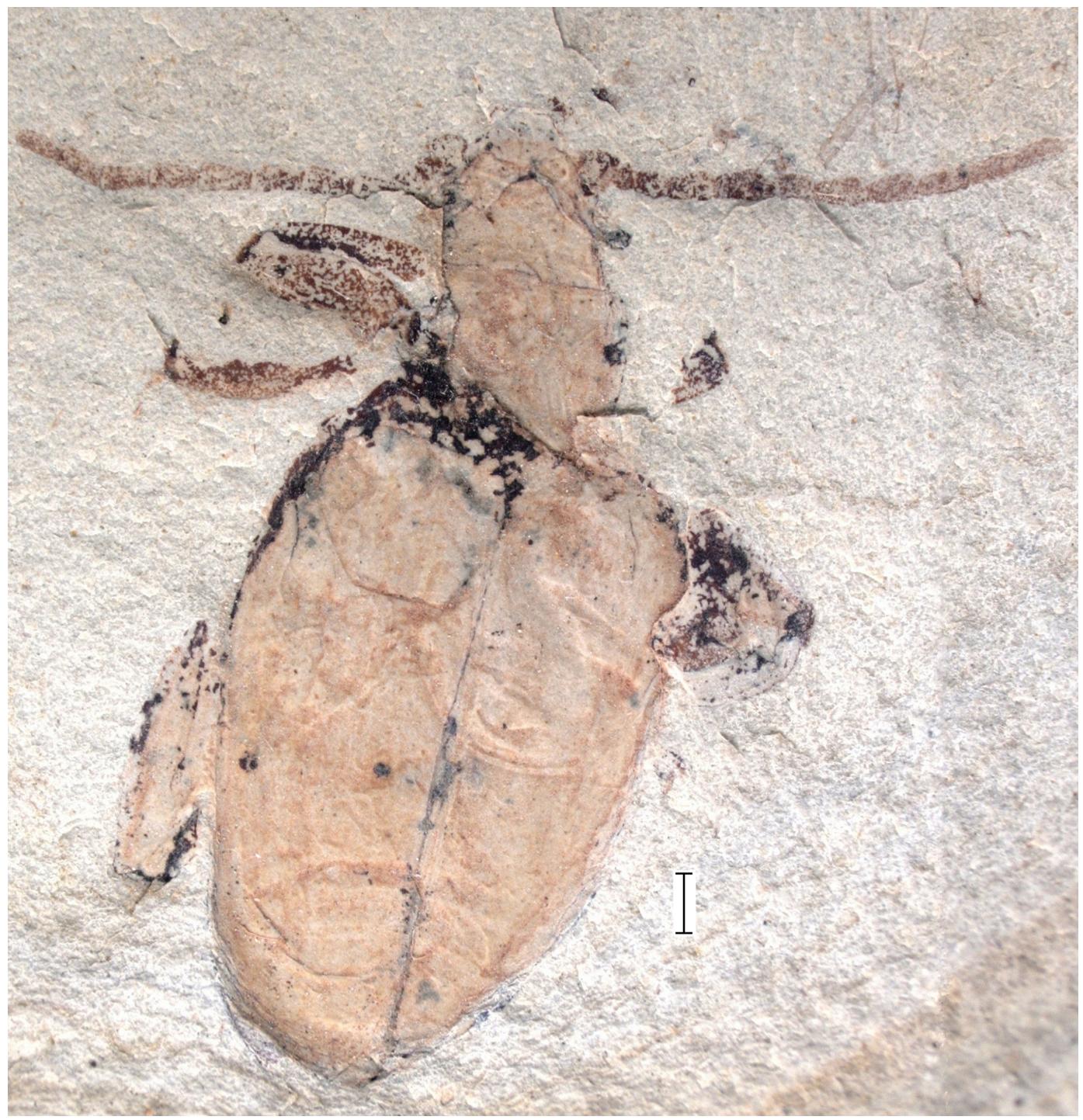

Figure 1. Body of the counterpart of Palaeatalasis monrosi sp. nov., holotype, GR2020/2 (ISEA). Scale bars $=1.0 \mathrm{~mm}$.

1.3 times as long as wide. Antennomeres $2-10$ conical. Antennomere 21.3 times as long as wide, 0.5 times as long as and 0.4 times as narrow as antennomere 1 . Antennomere 3 1.7 times as long as wide, 1.3 times as long as and equal in width to antennomere 2. Antennomere 42.0 times as long as wide, 1.3 times as long and 1.1 times as wide as antennomere 3. Antennomeres 5-9 subequal in width. Antennomere 52.4 times as long as wide, 1.4 times as long as antennomere 4. Antennomere 61.8 times as long as wide, 0.7 times as long as antennomere 4. Antennomeres 7-10 subequal in length. Antennomere 72.2 times as long as wide, 1.3 times as long as antennomere 6 . Antennomere 10 2.8 times as long as wide, 1.1 times as long as and 0.9 times as narrow as antennomere 9. Antennomere 113.0 times as long as wide, 1.1 times as long as and equal in width to antennomere 10 , weakly pointed at apex.
Pronotum. Weakly transverse, with subparallel sides, 0.9 times as long as wide in middle. Base 0.6 times as narrow as elytral base.

Elytra. Suboval, with weak humeri, weakly striate, 1.9 times as long as wide at base, 1.6 times as long as wide in middle, 2.3 times as long as wide at apical fourth, 3.6 times as long as pronotum. Interstriae quite wide. Punctate striae weak, with small rounded and dense punctures.

Thorax. Metacoxal cavities transverse.

Legs. Profemora and mesofemora moderately thickened. Metafemora enlarged without tooth, distinctly larger than other femora. Tibiae slightly curved, with carina. Mesotarsomere 1 conical. Mesotarsomere 3 bilobed.

Abdomen. Abdominal ventrite 1 long, 1.5 times as long as metacoxal cavity length. Ventrite 20.4 times as long as ventrite 1 . Ventrite 30.8 times as long as ventrite 2 . Ventrite 4 


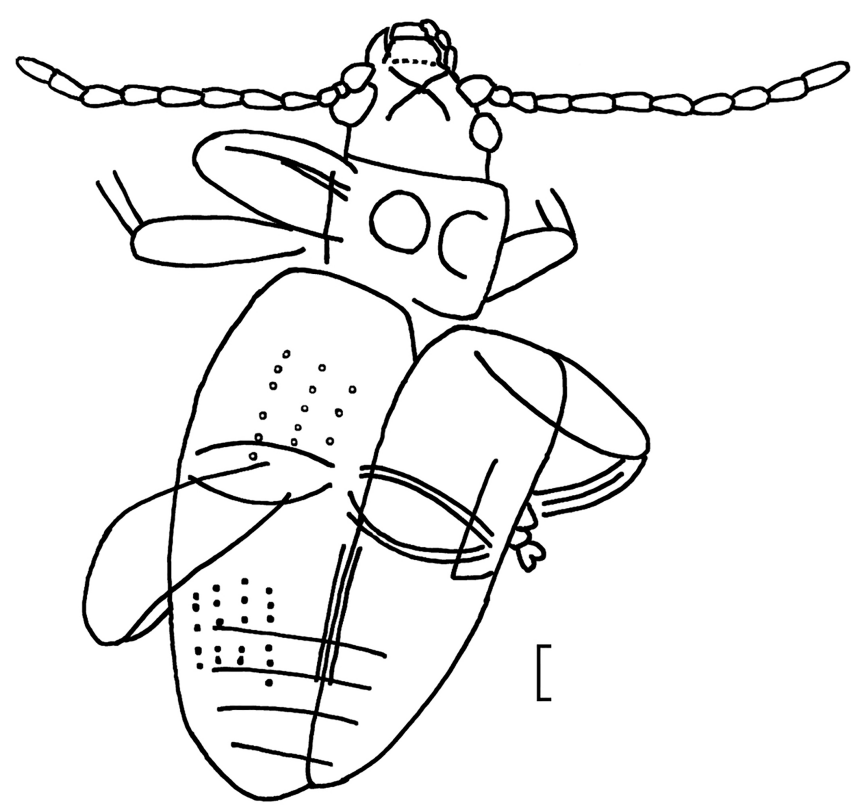

Figure 2. Body outline of the counterpart of Palaeatalasis monrosi sp. nov., holotype, GR2020/2 (ISEA). Scale bars $=1.0 \mathrm{~mm}$.

1.23 times as long as ventrite 3 . Ventrite 5 slightly longer than ventrite 4 .

\section{Discussion}

Members of the Sagrinae were found in the middle Paleocene of France (Legalov et al., 2019) and the Eocene of Germany (Wappler, 2003; Wedmann, 2018). Formerly they were not known from the rich Lagerstättten of the United States, such as the Green River and Florissant, nor from Eocene Baltic amber (Kirejtshuk and Ponomarenko, 2018). This study is the first record of Sagrinae from North America. The Paleocene and Eocene Sagrinae belong to the tribe Megamerini, which is now distributed in Australia and southern South America and Madagascar (Monrós, 1960). This subfamily is now absent from the central and northern parts of South America, central and North America, the West Indies, the African deserts, and also the Palaearctic. In the Western Hemisphere, the Sagrinae are distributed (Fig. 3) in tropical Africa, Madagascar, South and Southeast Asia, the Sunda Islands, and New Guinea, but the centre of their diversity is located in Australia. It can be assumed that Megamerini were previously distributed on all continents and were the most ancient and primitive Sagrinae. Primitive characteristics of the Megamerini are the striate elytra, convex, non-emarginate eyes, and head without rostrum.

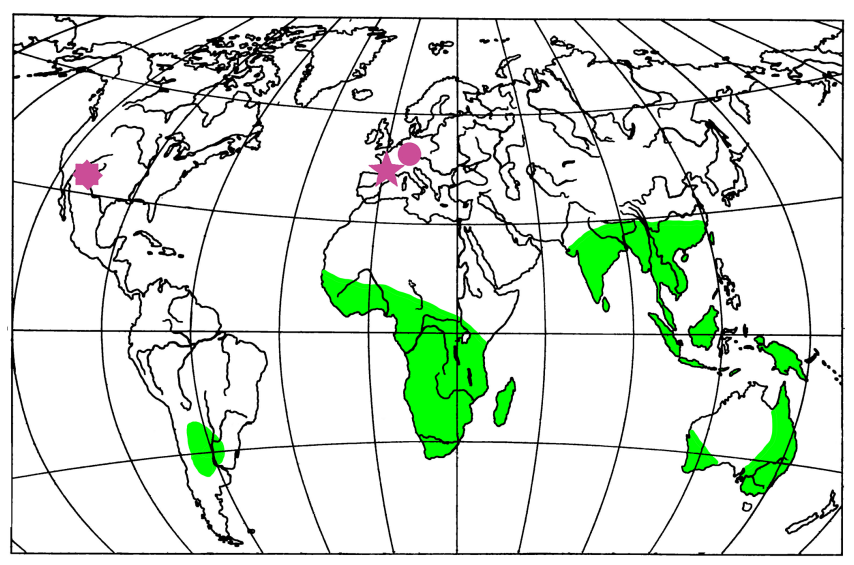

Figure 3. Distribution of Sagrinae: Recent members - green shaded area, octagram - fossil record from the Green River, star - record from Menat, circle - German Eocene record.

Sample availability. The specimen is deposited in the Institute of Systematics and Ecology of Animals, Siberian Branch, Russian Academy of Sciences.

Competing interests. The author declares that there is no conflict of interest.

Acknowledgements. The author thanks Boris A. Korotyaev and Alexey G. Moseyko (St. Petersburg) for the opportunity to study comparative material of the subfamily Sagrinae from the Zoological Institute RAS, George O. Poinar, Jr. (USA: Corvallis) for improving the manuscript, and two reviewers for valuable suggestions.

Review statement. This paper was edited by Florian Witzmann and reviewed by two anonymous referees.

\section{References}

Askevold, I. S.: Classification of Tertiary fossil Donaciinae of North America and their implications about evolution of Donaciinae (Coleoptera: Chrysomelidae), Can. J. Zool., 68, 2135-2145, https://doi.org/10.1139/z90-297, 1990.

Bieńkowski, A. O.: The first record of reed beetles (Coleoptera, Chrysomelidae, Donaciinae) in the early Paleocene of Amur region, Paleontol. J., 49, 51-56, https://doi.org/10.1134/S0031030115010025, 2015.

Bouchard, P., Bousquet, Y., Davies, A. E., Alonso-Zarazaga, M. A., Lawrence, J. F., Lyal, C. H. C., Newton, A. F., Reid, C. A. M., Schmitt, M., Ślipiński, S. A., and Smith, A. B. T.: Family-group names in Coleoptera (Insecta), ZooKeys, 88, 1972, https://doi.org/10.3897/zookeys.88.807, 2011.

Bukejs, A.: New genus and species of Lamprosomatinae (Coleoptera: Chrysomelidae) from Eocene 
Baltic amber, Palaeontol. Electron., 22.2.35A, 1-10, https://doi.org/10.26879/905, 2019.

Bukejs, A. and Nadein, K.: First fossil Lamprosomatinae leaf beetle (Coleoptera: Chrysomelidae) with descriptions of new genera and species from Baltic amber, Zootaxa, 3931, 127-139, https://doi.org/10.11646/zootaxa.3931.1.9, 2015.

Bukejs, A. and Schmitt, M.: Lilioceris groehni sp. $\mathrm{n}$. .: the first authentic species of Criocerinae (Coleoptera, Chrysomelidae) from Baltic amber, ZooKeys, 618, 67-77, https://doi.org/10.3897/zookeys.618.10085, 2016.

Chaboo, C. S. and Engel, M. S.: Eocene tortoise beetles from the Green River Formation in Colorado, U.S.A. (Coleoptera: Chrysomelidae: Cassidinae), Syst. Entomol., 34, 202-209, https://doi.org/10.1111/j.1365-3113.2008.00456.x, 2009.

Chapuis, F.: Histoire naturelle des Insectes. Genera des coléoptères ou exposé méthodique et critique de tous les genres proposés jusqu'ici dans cet ordre d'insectes. Tome dixième. Famille des phytophages, Librairie Encyclopédique de Roret, Paris, iv + 455 pp., 1874.

Cockerell, T. D. A.: Eocene Insects from the Rocky Mountains, Proc. U.S. Nat. Mus., 7, 233-260, https://doi.org/10.5479/si.00963801.57-2313.233, 1921.

Emery, C.: Über Phylogenie und Systematik der Insekten, Biol. Centralblatt, 5, 648-656, 1886.

Haupt, H.: Beitrag zur Kenntnis der eozänen Arthropodenfauna des Geiseltales, Nova Acta Leopoldina, (N.F.), 18, 1-90, 1956.

Haupt, H.: Die Käfer (Coleoptera) aus der Eozänen Braunkohle des Geiseltales, Geologica, 6, 1-168, 1950.

Kirejtshuk, A. G. and Ponomarenko, A. G.: A systematic list of fossil beetles of suborder Scarabaeina (3rd part), Catalogue of fossil Coleoptera, Beetles (Coleoptera) and Coleopterologists, Zoological Institute of the Russian Academy of Sciences, St. Petersburg, updated May 2018, available at: https://www.zin.ru/Animalia/ Coleoptera/rus/paleosy2.htm (last access: 10 May 2021), 2018.

Kirejtshuk, A. G., Moseyko, A. G., and Ren, D.: Mesozoic leaf beetles of the tribe Mesolpinini trib. nov. (Coleoptera, Chrysomelidae) from the Lower Cretaceous, Paleontol. J., 49, 1424-1435, https://doi.org/10.1134/S0031030115130043, 2015.

Lacordaire, J. T.: Monographie des coléoptères subpentamères de la famille des phytophages, Tome premier, Mém. Soc. Roy. Sci. Liège, 3, liii + 740 pp., 1845.

Latreille, P. A.: Histoire Naturelle, Générale et Particulière, des Crustacés et des Insectes. Ouvrage faisant suite aux Oeuvres de Leclercq de Buffon, et partie du Cours complet d'Histoire naturelle rédigé par C. S. Sonnini, membre de plusieurs Sociétés Savantes, 3, Dufart, Paris, xii + 467 pp., 1802.

Lawrence, J. F., Beutel, R. G., Leschen, R. A. B., and Ślipiński, S. A.: Chapter 2. Glossary of Morphological Terms, in: Handbook of Zoology. Arthropoda: Insecta. Tb. 40: Coleoptera (Beetles), Vol. 2: Morphology and Systematics (Elateroidea, Bostrichformia, Cucujiformia partim), edited by: Kristensen, N. P. and Beutel, R. G., Walter de Gruyter, Berlin/New York, 9-20, 2010.

Leach, W. E.: Entomology, in: Brewster's Edinburgh Encyclopedia, Vol. IX, part I. W, 57-172, edited by: Brewster, D., Edinburgh, 764 pp., 1815.
Legalov, A. A., Kirejtshuk, A. G., and Nel, A.: The oldest genus of the subfamily Sagrinae (Coleoptera: Chrysomelidae) from the Paleocene of Menat (France), C. R. Palevol., 18, 178-185, https://doi.org/10.1016/j.crpv.2018.10.003, 2019.

Legalov, A. A., Kirejtshuk, A. G., and Anokhin, B. A.: The oldest seed beetle (Coleoptera; Chrysomelidae: Bruchinae) from Upper Cretaceous amber of northern Myanmar with description of new tribe, genus and species, Cretaceous Res., 107, 1-5, https://doi.org/10.1016/j.cretres.2019.104283, 2020.

Linnaeus, C.: Systema Naturae per regna tria naturae, secundum classes, ordines, genera, species, cum caracteribus, differentiis, synonymis, 10, L. Salvii, Holmiae, 824 pp., 1758.

Monrós, F.: Los géneros de Chrysomelidae (Coleoptera), Opera Lilloana, 3, 1-337, pls. 1-3, 1960.

Moseyko, A. G., Kirejtshuk, A. G., and Nel, A.: New genera and new species of leaf beetles (Coleoptera: Polyphaga: Chrysomelidae) from lowermost Eocene French amber, Ann. Soc. Entomol. France (n.s.), 46, 116-123, https://doi.org/10.1080/00379271.2010.10697645, 2010.

Nadein, K. S. and Perkovsky, E. E.: A new tribe of Galerucinae leaf beetle (Insecta: Coleoptera: Chrysomelidae) from the Upper Cretaceous Taimyr amber, Cretaceous Res., 84, 97-106, https://doi.org/10.1016/j.cretres.2017.10.023, 2018.

Piton, L.: Paléontologie du gisement éocène de Menat (Puy-deDome), flore et faune, Mém. Soc. Hist. Nat. Auvergne, ClermontFerrand, 1, 1-303, 1940.

Reid, C. A. M.: Chapter 2. Chrysomeloidea Latreille, 1802, in: Handbook of Zoology. Arthropoda: Insecta. Tb. 40: Coleoptera (Beetles), Vol. 3: Morphology and Systematics (Phytophaga), edited by: Leschen, R. A. B. and Beutel R. G., Walter de Gruyter, Berlin/New York, 11-15, 2014.

Santiago-Blay, J. A.: Paleontology of leaf beetles, in: Novel aspects of the biology of Chrysomelidae, edited by: Jolivet, P. H. A., Cox, M. L., and Petitpierre, E., Kluwer Academic Publishers, the Netherlands, 1-68, https://doi.org/10.1007/978-94-0111781-4_1, 1994.

Scudder, S. H.: The fossil insects of the Green River shales, Bull. U.S. Geol. Geogr. Surv. Terr., 4, 747-776, 1878.

Wappler, T.: Die Insekten aus dem Mittel-Eozän des Eckfelder Maares, Vulkaneifel, Mainzer Naturwissenschaftliches Archiv, 27, 1-234, 2003.

Wedmann, S.: Chapter 7. Jewels in the Oil Shale - Insects Other Invertebrates, in: Messel-An Ancient Greenhouse Ecosystem. Senckenberg Bücher, Nr. 80, 63-104, edited by: Smith, K. T., Schaal, S. F. K., and Habersetzer, J., Schweizerbart Science Publishers, Stuttgart, 2018. 